\title{
Accounting Disclosure for Financial Instruments: Financial Leverage Risk and Liquidity and their impact on Earnings per Share and Dividends Yield
}

\author{
Nevine Sobhy Abdel Megeid \\ Associate Professor of Accounting \\ College of Management and Technology
}

Arab Academy for Science, Technology and Maritime Transport

nevinesobhy2@hotmail.com



الغرض من هذا البحث هو اختبار تأثير الإفصاح المحاسبي عن الر افعة المالية ووضع السيولة على

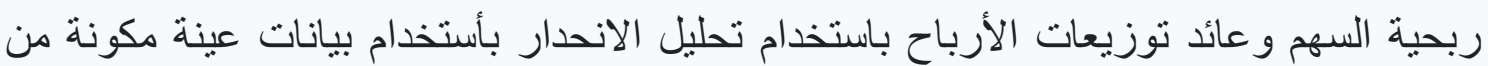

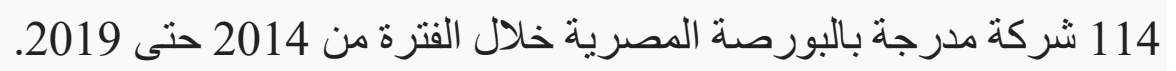

وتوضح درجة الر افعة المالية المستوى الذي استخدمت فيه الثركة الدين الخارجي لتمويل عملياتها. أظهرت النتائج وجود نأثثر إيجابي للربحية على كل من ربحية السهم و عائد توزيعات الأرباح. أظهرت النتائج أيضًا أن جميع المتغيرات المستقلة الأخرى (الر افعة المالية والسيولة) لها ارتباط سلبي مع كل من ربحية السهم وعائد الأرباح. يتطابق هذا البحث مع الأبحاث الأخرى التي أجريت

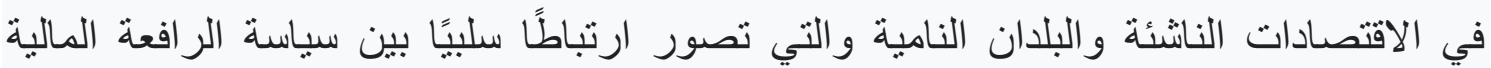
وتوزيع الأرباح ، حيث تحتاج الثركات إلى الحفاظ على مسنوى سيولة كافٍ لسداد ديونها.

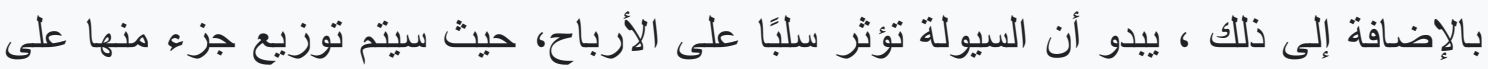

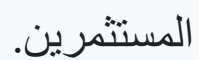

وتعتبر الر افعة المالية أساسية لأنها تؤثر على الثركة التي تحتاج إلى زيادة فرص نموها ، بسبب

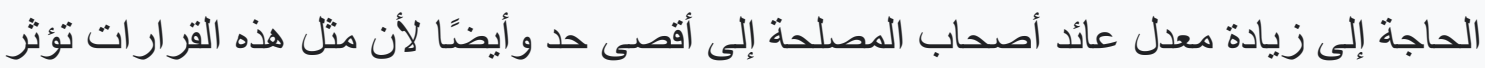
بشكل كبير على قدرة الثركات على التعامل مع البيئة المالية التنافسية المحيطة. نثير النتائج إلى الى أنه وفقًا لمعاملات الارتباط بين متغيرات البحث ، فإن كلا من ربحية السهم وعائد نوزيعات

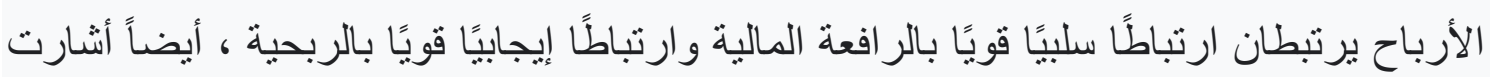

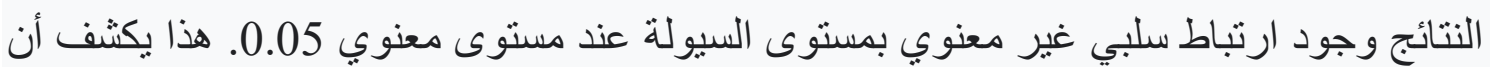


الر افعة المالية والأداء المالي يؤثران على سياسة توزيع الأرباح.بناءً على نتائج الانحدار ، فإن النا السيولة لها علاقة سلبية بالر افعة المالية حيث أن الثركات ذات الر الراهي الفعة المالية الأعلى لديها القليل

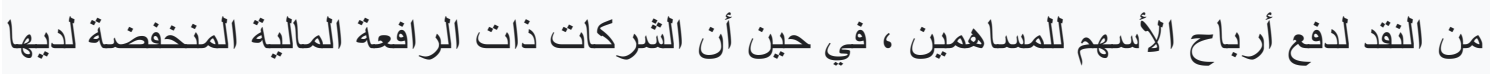

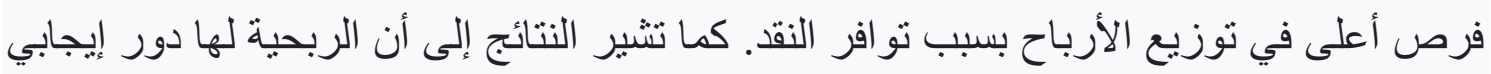

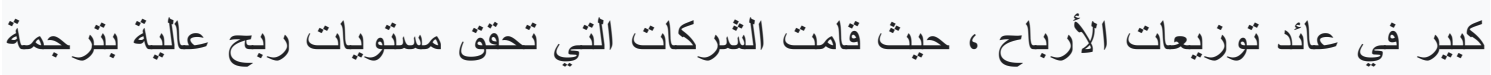

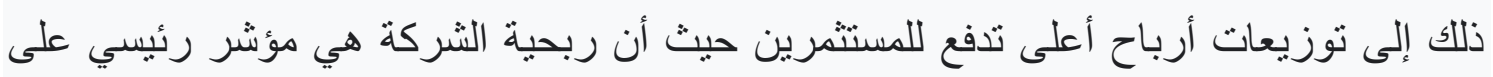
قدرتها على توزيع الأرباح. ويتمثل الهدف النهائي للثركة في تعظيم ثروة مساهميها ويمكن تحقيق ذللك من خلال الأرباح المرتفعة لكل سهم. يتم دفع عائد السهم من صافي الدخل بعد الضريبة ، لذللك يعتبر عاملاً مهمًا يؤثر بشكل كبير على توزيعات الأرباح. توجد علاقة إيجابية كبيرة بين ربحية السهم ومقدار

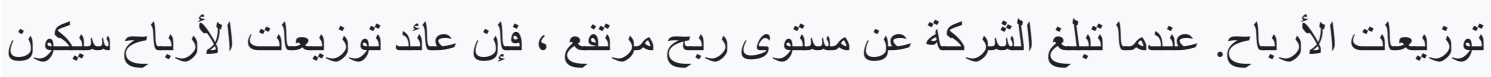
بدوره أعلى. و أنثارت النتائج إلي ان لربح السهم تأثثر معنوي على توزيعات الأرباح. هذا يعني أنه إذا كان

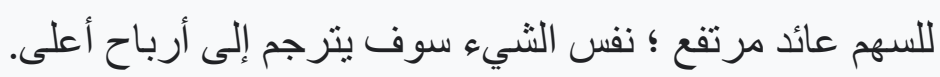

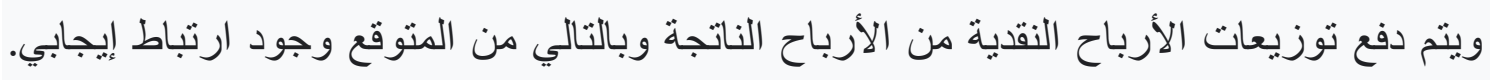

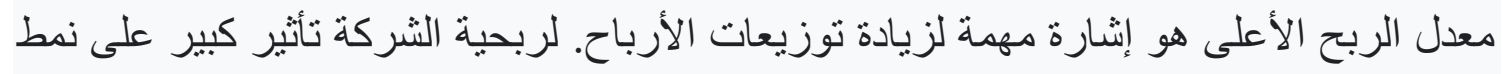

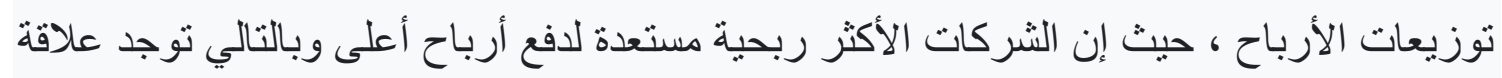
إيجابية مهمة بين ربحية الثركة ودفع توزيعات الأرباح.

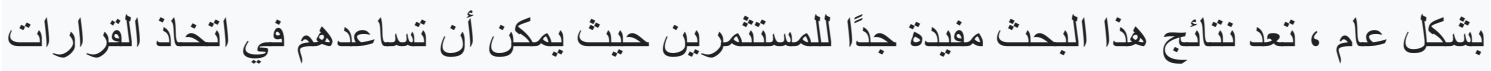

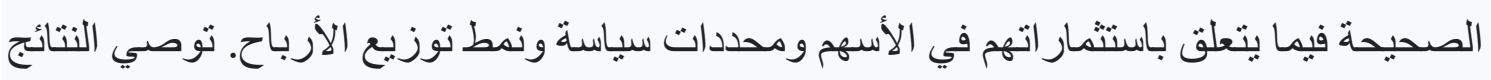

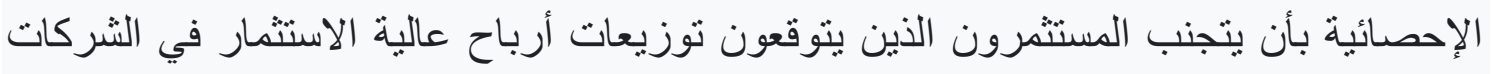

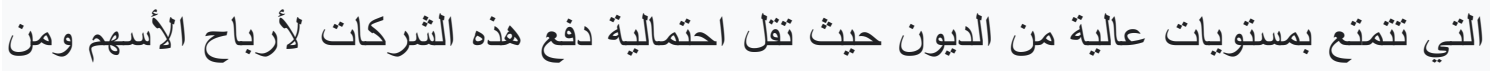

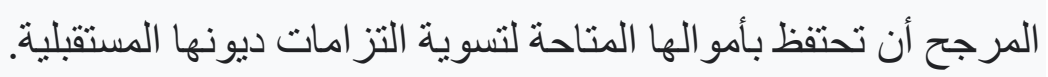






\begin{abstract}
Accounting disclosure for financial instruments through analyzing the actual accounting data are used as a vital market measures for financial leverage risk (debt and fixed costs) and assist in decision making as adding financial leverage always adds risk to both the levered company and investor. Degree of financial leverage is an important factor in determining financial risk level and it has direct effect on dividends policy, as it causes intensification of the change in earnings per share percentage because if degree of financial leverage is larger, it may be negative by slight decrease in profit before interest and taxes.

The main objectives of this research are to examine the association between financial leverage and liquidity and their impact on earnings per share and dividends yield respectively. The sample taken is 114 listed companies across different industries in Egyptian Stock Exchange for the period from year 2014 to 2019. The Ordinary Least Square regression analysis is used to find the relations between The Financial Leverage Risk (FLR) and Liquidity (LQ) as independent variables and Earnings per Share (EPS) and Dividends Yield (DY) as dependent variables for this research, using Profitability (ROE) and Industry type (IND) as control variables.

Financial leverage is fundamental as it affects a firm that needs to increase its growth opportunity, because of the need to maximize stakeholders rate of return and also because such decisions impact greatly the ability of firms to deal with the surrounding competitive financial environment. Findings indicate that according to the correlation coefficients among the research variables, both earnings per share and dividends yield are negatively strong correlated with leverage and strong positively correlated with profitability, and has insignificant negative correlated with liquidity level, at 0.05 significant level. This reveals that financial leverage and financial performance influences the dividends policy.
\end{abstract}

Keywords: - Financial Leverage Risk; Liquidity; Earnings per Share; Dividend Yield; Profitability.

\title{
1. Introduction
}

Financial risk is defined as the risk of a company failing to meet its obligations due to inappropriate capital structure management and inadequate liquidity. 
The accounting disclosures on the capital structure of the company is vital, it shows how the company finances its overall business operations and growth through the use of hybrid instruments for funding, including ordinary equity and debt. The overall goal of management decision is to ensure diversity and efficiency of its capital structure to support the achievement of the expected returns to shareholders

Generally, standard setters' requirements influence reporting of risk through setting financial accounting standards. Risk reporting is correlated with the measure of leverage and corporate dividend policy.

Accounting directors and accountability function support decisions regarding financial risk and corporate dividend policy decision-making as the annual financial statements provide information for risk disclosure. Financial managers are delegated to put the financial policies and make decisions related to the amount of net earnings that will be distributed to stockholders.

Corporate dividend policy is viewed by Ross et al., (2011) as the amount of profit to be distributed to the stockholders and those to be retained for reinvesting in expansion or other profitable projects or for future contingences.

Dividend is a form of reward to investors who take the risk and invest in the company stock. Dividend distribution to stockholders is a board of director's decision. Commonly, distributions to stockholders are in cash dividend form (Margaret et al., 2015). Cash dividends require cash outflow, noting that for the business conduct, previous year's profits are already invested in assets and not held in cash form.

According to Gill et al., (2010) for investors, dividends is consider their net profits share in a company that distributed to them to provide secure current income and also help to maintain market price of their shares. Dividend payout is attractive and critical issue as it provides them to somehow certainty about the wellbeing of firm's financial position.

Dividend payout policy affected and determined by many factors such as shareholders need for income and the company's financial needs. An expansion and growing firm may need more funds for expansion operations, therefore it may prefer to retain its earnings as this will much cheaper than external equity financing, which require dividend payout.

Capital structure of a firm affects its financial leverage and dividends policy. Capital structure is a financing combination of debt and equity. Financial leverage is a "trading on the equity" financial technique, it is the 
percentage of total debt to the equity of a company, and it reflects the ability of the company to attract external funds to improve its equity efficiency.

In the firm capital structure, financial leverage degree represents the use of additional borrowed funds (debt) in form of fixed-cost debt instruments, as: bonds and loans, to make an investment and return on that investment. Financial leverage, influence significantly the firm's ability to maximize its shareholders wealth through maximizing the return in equity, which is the ultimate goal of any firm. This is because, increased in leverage correlated with both increase in risk and returns, and vise versa. The use of leverage is may either have a positive outcome which is maximizing the profit (i.e. the cost of borrowing is lower than the rate of return) or negative outcome which is minimizing the profits (i.e. High debt and risk level). High interest obligations are a result of increased financial leverage risk. Consequently, the earnings per share are driven lower and adversely affected by this fixed interest payments.

This in turn, increase risk to stockholder return, thus when making financing decisions, a firm should consider in mind, the balance of its capital structure as debt always attributed with a high risk as it must be paid off, so that it need to manage and ensure that any increase in debt will increase the company value and maximize the return in equity for shareholders (Perinpanathan, 2014).

Highly financial leveraged firms pay lower dividends reduce their transaction costs and to fulfill their responsibility by maintain internal cash flow and to protect creditors (Gugler and Yurtoglu, 2003).

Dividends and liquidity position are very linked, liquidity should be considered in financial leveraged firms and in determining the firm dividend paying out policy, this is because distributing cash dividends do not depends only on the firm's profitability but also on the free cash flow (i.e. the amount of operating cash flow remain after deducting capital expenditures for fixed assets).

Liquidity indicates ability of a firm to meet its current payment obligations when they came due. Proper liquidity management is critical as it balance between current assets (cash and near-cash) and current liabilities and ensure the elimination of obligations default when their due arise (Eljelly, 2004).

When the current liabilities of the firm are higher than its current assets, this indicates that the firm might be ineffective and face financial 
difficulties in paying its current obligations. In turn, this can affect the firm's current operations and its ability to pay dividends (Margaret et al., 2015). Thus, rational investors usually expect to demand a premium return in compensation for holding less liquid assets. Therefore, theoretically, there should be a positive association between stock returns and illiquidity. And vise versa, the association between stock returns and liquidity should be negative (Dalgaard, 2009). Risk adverse investors who are more uncertain about future cash flows, expects a higher rate of return and dividends payout on their investment (Penman et al., 2007).

Generally, financial leverage has two sides, it can increase shareholders' rate of return and as well can increase the company's financial risk also.

The rest of this research is organized as follows: Section 2 presents literature review. Section 3 introduces the research objectives. Section 4 presents the research questions and hypotheses. Section 5 demonstrates the research methodology and theoretical framework in section 6. Section 7 discusses regression models and variables measurements. Section 8 presents the results of statistical tests of the underlying hypotheses and discusses the empirical findings. Finally, section 9 concludes.

\section{Literature Review}

According to the literature review, many factors can affect the dividend policy and decision making. Firm size, liquidity profitability, risk of financial leverage, investment opportunities, retained earnings; tax shields and firm rate of growth are widely tested and determined as dividend policy determinants.

Mohamed et al. (2016) tested the factors influence dividend payment measured by market capitalization - on Malaysian stock markets for the period 2003-2005. Findings determine that liquidity and profitability are the main determinants of dividend payment and that larger firms have higher likelihood for paying dividend and that fast-growing firms are on average paying dividends that are 40 percentages of their earnings attract potential investors and satisfy current ones.

Komrattanapanya and Suntrauk (2013) examined the determinants which affect the dividend payment in the Thailand Stock Exchange. Findings concluded that investment opportunities, sales growth rate and financial leverage inversely impact dividend payout; conversely, firm size is 
affecting positively dividend payout. On the other hand, liquidity, profitability, and business risk have immaterial relationship to dividend payout.

Rehman (2013) examined the impact of financial leverage on financial performance Pakistan listed sugar companies. Findings indicate that there is a positive association between financial leverage ratio and ROA and rate of sales growth, and negative association between financial leverage ratio and earning per share, gross margin and ROE, this negative association support indicate that when the company uses more debt, the more interest obligation and payment, thus EPS will in turn decrease.

Essa et al., (2012) examined the dividend policy in Jordan, by testing the impact of net cash flows, EBIT, EPS, price / book value ratio, dividends yield, and firm size as determinateness of dividend payment policy as dependent variable. Findings indicate that EPS have a significant impact on dividends policy, followed by dividends yield and then price to book value ratio. Also, there is a negative association between dividends policy and leverage ratio and those small firms have less impact on dividends policy than large firms.

Aasia (2011) tested the impact of the debt ratio on the dividend decisions (dividend per share) in the Karachi listed companies using dividend yield, leverage ratio, and the earnings changes as independent variables. Findings indicate that the leverage ratio has insignificant impact on the dividend decisions, while the dividend yield has positive impact and vice versa.

Khan, Burton and Power (2011) shows that in Pakistan companies the factors affect the dividend payout is based on the current year earnings, liquidity levels and the pattern of past dividends payout, and that dividend decisions are negatively affected by financial leverage level.

Ross et al., (2011) indicate that small and less profitable companies have low dividends payments as they have low liquid position, as they reinvest most of their earnings again, in contrast with large and profitable companies, that generate much cash over their needs thus they distributed this surplus as dividends to stockholders.

Afza and Mirza (2010) showed that companies' with better financial and liquidity position has key role in dividend policy decision making.

Gill, Biger and Tibrewala (2010) found in service industry, positive association between dividend payout and profitability which in contrast, in manufacturing industry profitability affect dividend payout adversely. 
Okpara (2010) noticed that in Nigeria's firms, earnings, liquidity and past years dividends payments have a positive impact on the dividend payout ratio.

Attiya (2009), found that stable firms have positive cash flow and profitability to pay more dividends and that structure of ownership and firm liquidity have positive significant impact on dividend policy and decisions, while having current investment opportunities and financial leverage obligations have negative impact on dividend payout.

Pandey (2008) viewed highly financial levered company as the one that use debt (borrowing) in its financing which are reinvested to get a return and the financial level of leverage is the change in income after tax as result to changes in EBIT. Thus, financial leverage leads to variability in the returns of stockholders and increase company financial risk and in turn, the company equity risk (beta). If the loan interest expense is lower than the company's ROA, then its ROE will be higher if it did not use debt. Conversely, if the company has higher interest expense than ROA, then its ROE will be lower than if it did use debt. Financial leverage can lead in the short-term to greater returns to the shareholder, while in the medium term, potential loss will be higher, if the investment is not successful and worthy and the company still has the obligation for the accrued interest and loan principal amount.

Twaijry (2007) found that dividend payout has insignificant relationship with earnings. On other hand the degree of financial leverage is inversely related with the dividend payout.

Watson and Head (2007) argued that for companies that consider paying high dividends must first evaluate their liquidity positions and profits. They stress on the fact that the firm cash flow is not the same as profits, thus, the amount of dividends payment should reflect its ability to pay dividends (liquidity) not only its company withstanding profits.

Watson and Head (2007) shows that for a company that is willing to declare cash dividends, it must first have adequate earning and enough cash for dividends payments otherwise it will have a liquidity problem. Lenders may affect dividends policy by putting loan covenants on dividend payment to guarantee that their interest will be paid on time even when a firm is has low liquidity or less profitable.

Liu and $\mathrm{Hu}$ (2005), stated that if the free cash flow is greater than the cash dividend, this indicate that the firm has enough cash to pay dividends, and 
if the opposite is the case, this indicate that the firm require more finance to meet the requirement of cash dividends.

Kumar (2003) studied the factors affecting dividend policy in India for the period (1994-2000). Finding indicates that dividend payout is positively related on earnings trends, while negatively related with financial leverage. Banerjee et al., (2002) found that a firm with good liquidity position has less financial risks and has a positive relationship with a company's dividend payout (having the ability to pay more dividends).

Thompson (2000) stated that (financial leverage) debt/equity ratio is the relationship between the amount financed through debt and owner contribution in the firm. The degree of financial leverage significantly affects the shareholder payoff. Financial leverage level impact directly the EPS and on the ROE of a firm as the degree of financial leverage of a firm can magnifies both the gain and loss of the shareholder.

Curran (1987) stated that financial leverage is measured by the ratio between the borrowed money (debt) and the shareholder contributed capital (equity).

Ben-Zion and Shalit (1975) examined the effect of firm size, financial leverage and dividend payments on common stock risk. Findings indicate that firm's risk and leverage has significant adverse relationship with firm size and dividend yield.

According to the trade-off theory, higher risk should be associated with high debt, because future cash flows may not be sufficient to repay the debt. This potential bankruptcy risk increases the cost of borrowing and reduces the firm's ability to raise debt capital (Kraus and Litzenberger, 1973).

Kent (1960) showed that having positive earnings is not enough to declare cash dividends because the firm should evaluate first its liquidity position. The ability of a firm to pay dividends is strengthened by its good liquidity position.

Generally, previous studies on this area do not agree about whether there is a positive or negative relationship between debt/equity and dividends payout or yield. This current research aims at fill this gap and examines the effect of financial leverage and liquidity on earnings per share and dividends yield by companies listed at the Egyptian stock exchange market.

\section{Research Objectives}


In the Egyptian's context, there is no research has been done to indicate whether there is an effect of financial leverage and liquidity position on earnings per share and dividend yield by companies listed at stock exchange market, and therefore this research aims to fill this gap.

\section{The main objectives of this research are to:}

1. Determine the relationship between financial leverage and the liquidity position of listed companies.

2. Help the investors and portfolio managers in their managerial policy and financial decision making such as dividend distributions and leverage decisions by assisting them in the understanding, identifying, analyzing, and assessing the impact of financial leverage risk and liquidity on both earnings per share and dividends yield.

3. Compare the significant impact of profitability, liquidity, and leverage according to the type of industry sector.

\section{Research Questions and Hypotheses}

\section{In particular, this research aims to answer the following research questions:}

1. To what extent does the effective balance liquidity and profitability management influence companies' financial leverage ratio?

2. To what extent does the effective balance between financial leverage, liquidity and profitability have a significant and positive impact on companies' earnings per share?

3. To what extent does the effective balance between financial leverage, liquidity and profitability have a significant and positive impact on companies' dividend yield ratio?

\section{In light of the research objectives, the following hypotheses are tested:}

$\mathbf{H}_{1}$ : There is an interaction between financial leverage risk, liquidity position and profitability of all firms under selected sectors.

$\mathbf{H}_{2}$ : There is a significant effect of financial leverage risk and profitability on earnings per share of all firms under selected sectors.

$\mathbf{H}_{3}$ : There is a significant effect of liquidity position on earnings per share of all firms under selected sectors. 
$\mathbf{H}_{4}$ : There is a significant effect of financial leverage risk and profitability on dividend yield of all firms under selected sectors.

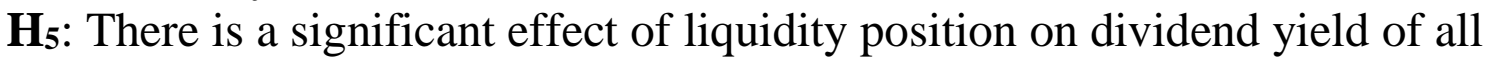
firms under selected sectors.

\section{Research Methodology}

This research conducted using data from 114 publically listed non-financial companies listed in the Egyptian stock exchange (EGX) from the year 2014 till 2019. We exclude those financial firms due to their distinct financial nature. Financial and secondary data were obtained from the financial statements and the published annuals reports.

Based on the financial data from all public listed companies in Egypt stock exchange market, The sample consists of 114 industrials companies as follows: 4 basic resources companies, 7 chemicals companies, 18 construction and materials companies, 15 financial services excluding banks, 21 food and beverages companies, 8 healthcare and pharmaceuticals companies, 8 industrial goods and services and automobiles companies, 1 oil and gas company, 7 personal and household products companies, 12 real estate companies, 2 retail companies, 1 media company, 2 technology companies, 2 telecommunications companies, 5 travel and leisure companies, and 1 utilities company.

To test the research stated hypotheses, the earnings per share and dividend yield ratio are used as the dependent variable and the ratios of the liquidity (current ratio) and financial leverage (debt/equity ratio) are used as the independent variables and both the profitability (ROA) and industry type are used as the control variables. All ratios have been computed over the six years horizon (2014-2019). The Statistical Package of Social Sciences (SPSS) tool was utilized to analyze the financial data by descriptive and inferential statistics (means, maximum, minimum and standard deviation) and (Pearson's correlation coefficients and simple linear regression) respectively.

\section{Theoretical Framework}

Based on the research objective, hypotheses and the theoretical framework constructed in figure (1), the dependent variables are the earnings per share 
and dividend yield and the independent variables are financial leverage risk concerned with the financial activities and liquidity and the control variables are profitability and industry type.

\section{Figure (1): Research Theoretical Framework}

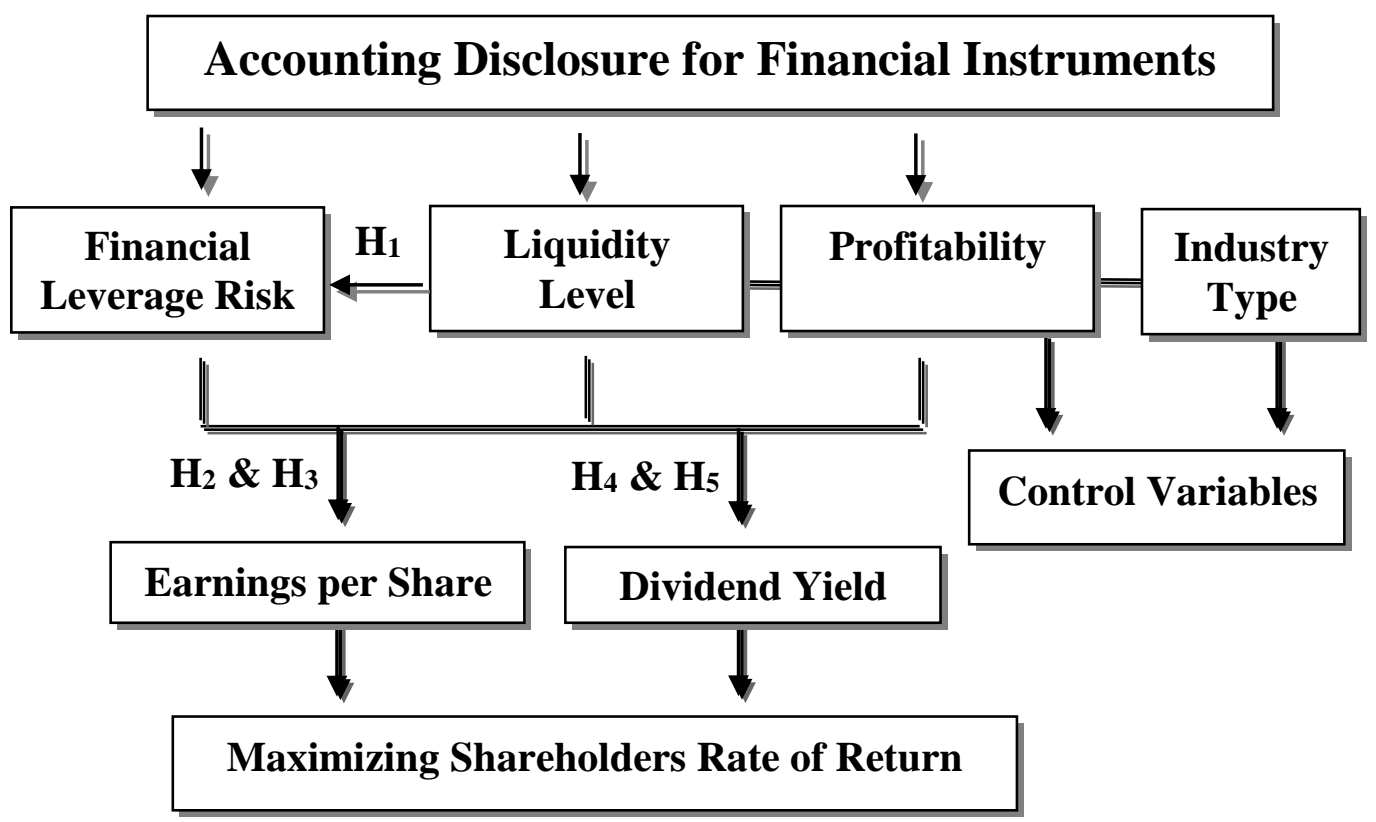

Generally, high financial leverage risk cause future earnings variability for common shareholders as a result to the use of more outsources debt to finance the assets acquisition. It increased the insolvency probability that comes with the excessive use of debt financing because of bearing a high interest cost on debt represent overwhelming on business as fixed obligation must be paid when due (Muhammad, 2016). It includes the use of those debts that are borrowed at fixed charges in the expectation of maximizing the shareholders rate of return in future. Normally, it is anticipated that the debt used by any company have to earn more return than their costs (fixed-charges) and the surplus will increase the return on investments and in turn the return on the owner's contributed capital and vice versa in case of deficit.

On the other point of view, as debt has a fixed borrowing cost, more debt allows the company to expect to earn a higher rate of return. Therefore, there is a trade-off between risk and return attributed to increasing (decreasing) debt. According to Gitman and Zutter (13 ${ }^{\text {th }}$ edition), financial leverage through debt financing contribute towards the company's 
profitability by tending to generate high profit that cover the higher fixed financial cost and to reduce the future possibility that company may fail to cover its interest obligations. The financial leverage used by a company is intended to earn more return on the fixed charges funds than their relative costs (Pandey, 2008).

Financial leverage risk related to the fixed obligation of interest on loans. Companies use the fixed interest charges to magnify the impact of changes in EBIT on profits (i.e. if degree of financial leverage is higher, it may be much negative by only slight decrease in EBIT). Houmani and Ghara (2013) found that when the degree of financial leverage is high, the level of financial risk increase, because the former may negatively decrease EBIT, thus financial leverage impact the earning per share of the company.

The ROE is levered above or below the rate of ROA. The degree of financial leverage is the percentage change in EPS caused by a given percentage change in EBIT (Elangkumaran and Nimalathasan, 2013), thus in order to increase the return of equity share holders, financial leverage is used. That's why financial leverage studies how EPS is sensitive to EBIT. Financial Leverage $=$ EBIT/ EBIT-I or EBT (Narayana et al., 2014).

Generally, under favorable and stable economic conditions, financial leverage can accelerate EPS and vise versa. The financial leverage has unfavorable severe impact on EPS when EBIT is negative

When the degree of financial leverage is high, this makes a company very sensitive to any small changes in earnings and has difficulty to raise external funds for the purpose of financing its expansion and growth. Therefore, in order to strengthen its equity base, this high leveraged companies with fluctuating incomes and poor liquidity, will expected to retain most of its earnings and are not able to pay much dividends. On contrary, when the company has a relatively stable earnings and good liquidity position, it is more certain and able to predict its future earnings and in turn is likely to pay higher dividends.

Jensen et al., (1992) showed that financial leverage have a negative impact on dividend payout, they found that higher leverage levels in the previous year correlate with lower dividends payout in the coming year, confirming that an increase in debt serves as a credible sign that a company expects high future rate of return and cash flows.

The liquidity of a firm depends on its financial decisions and investment opportunities which in turn determines the rate of its growth and expansion and its way of financing. In case of weak cash position, stock dividend will 
be preferable and if cash position is stable, cash dividend can be distributed.

\section{Regression Models and Variables Measurements}

The following three multivariable linear regression statistical models are used in this research in an attempt to test the stated hypotheses and to identify and examine the pattern of empirical relationship between the research variables. Table (1) presents the measurement and definitions for all the of research variables.

Table (1): Measurements of Research Variables

\begin{tabular}{|c|c|c|}
\hline Description & Symbols & Measurement \\
\hline $\begin{array}{l}\text { Dependent } \\
\text { Variable: } \\
\text { Earnings } \\
\text { Per Share }\end{array}$ & EPS & $\begin{array}{l}\text { Earnings per share indicate the company's profitability and } \\
\text { helps determining a stock's value. } \\
\text { Earnings per Share = } \\
\quad \text { Net income - Preferred Dividends } \\
\text { Weighted Average Number of Common Shares Outstanding }\end{array}$ \\
\hline $\begin{array}{l}\text { Dependent } \\
\text { Variable: } \\
\text { Dividends } \\
\quad \text { Yield }\end{array}$ & DY & $\begin{array}{l}\text { Dividend yield is used by investors to show how their } \\
\text { investment in stock is generating either cash flows in the } \\
\text { form of dividends or increases in asset value by stock } \\
\text { appreciation. } \\
\text { Dividend Yield }=\frac{\text { Annual Dividend per Share }}{\text { Current Price per Share }}\end{array}$ \\
\hline $\begin{array}{l}\text { Independent } \\
\text { Variable: } \\
\text { Financial } \\
\text { Leverage } \\
\text { Risk }\end{array}$ & FLR & $\begin{array}{l}\text { Financial leverage ratio is used to show the way the } \\
\text { company's is financed and indicate its ability to pay its } \\
\text { financial obligations. } \\
\text { Debt/Equity Ratio }=\frac{\text { Total Debt }}{\text { Shareholder's Equity }} \times 100\end{array}$ \\
\hline $\begin{array}{l}\text { Independent } \\
\text { Variable: } \\
\text { Liquidity }\end{array}$ & LQ & $\begin{array}{l}\text { Current ratio evaluates the company ability to meet its } \\
\text { short-term obligations due come due. } \\
\text { Current Ratio }=\frac{\text { Current Assets }}{\text { Current Liabilities }}\end{array}$ \\
\hline $\begin{array}{l}\text { Control } \\
\text { Variable: } \\
\text { Profitability }\end{array}$ & PRO & $\begin{array}{l}\text { Return on equity indicates a company's profitability by } \\
\text { revealing how much profit it generates with the capital } \\
\text { shareholders have invested. } \\
\text { Return on Equity }=\text { Net Income }- \text { Preference Dividends } \\
\text { Average Ordinary Shareholders' Equity }\end{array}$ \\
\hline
\end{tabular}




\begin{tabular}{|c|c|c|}
\hline $\begin{array}{c}\text { Control } \\
\text { Variable: } \\
\text { Industry } \\
\text { Type }\end{array}$ & IND & $\begin{array}{l}\text { The research managed to estimate an OLS regression with } \\
\text { the dummy industry variables as control variables in the } \\
\text { regression and got reasonable results. The research have a } \\
\text { data set with different companies that was grouped into } \\
\text { industry codes (created dummy variables for each industry } \\
\text { category) as follows: } \\
\text { The panel data set that contains around } 114 \text { companies, } \\
\text { covering a period of } 6 \text { years. We have segregated these } \\
\text { companies into } 16 \text { industries and i have created } 16 \text { dummy } \\
\text { variables (based on the code: reg yvar Ind } 2 \text { Ind3 } 3 . \\
\text { Ind16) that record under } 1 \text { if they are in that industry and } 0 \\
\text { if they are not. } \\
\text { Industry dummies representing industry j where j }=1 \text {, } 2 \text {, } \\
3, \ldots, 16 \text {. } \\
\text { IND } 1=\text { basic resources companies, IND } 2=\text { chemicals } \\
\text { companies, IND } 3=\text { construction and materials companies, } \\
\text { IND } 4=\text { financial services excluding banks, IND } 5=\text { food } \\
\text { and beverages companies, IND } 6=\text { healthcare and } \\
\text { pharmaceuticals companies, IND } 7=\text { industrial goods and } \\
\text { services and automobiles companies, IND } 8=\text { oil and gas } \\
\text { companies, IND } 9=\text { personal and household products } \\
\text { companies, IND } 10=\text { real estate companies, IND } 11=\text { retail } \\
\text { companies, IND } 12=\text { media companies, IND } 13= \\
\text { technology companies, IND } 14=\text { telecommunications } \\
\text { companies, IND } 15=\text { travel and leisure companies, IND } 16 \\
=\text { utilities companies. }\end{array}$ \\
\hline
\end{tabular}

First, the following regression model is used to study the interaction between financial leverage risk and liquidity position and how the later has impact on the former (using profitability, and company industry type as control variables).

The function of financial leverage risk ratio can be rearranged as follows:

\section{Where:}

$$
\begin{gathered}
\text { FLR }=f\left(\mathbf{L Q}_{\mathrm{it}}, \mathbf{P R O}_{\mathrm{it}}, \mathbf{I N D}_{\mathrm{it}}, \mathbf{T}_{\mathrm{i}}\right) \\
\mathbf{F L R}_{\mathrm{it}}=\boldsymbol{\beta}_{\mathbf{0}}+\boldsymbol{\beta}_{1} \mathbf{L Q}_{\mathrm{it}}+\boldsymbol{\beta}_{2} \mathbf{P R O}_{\mathrm{it}}+\boldsymbol{\beta}_{\mathbf{3}} \mathbf{I N D}_{\mathrm{it}}+\mathbf{T}_{\mathrm{i}}+\varepsilon \mathrm{il}_{\mathrm{t}}
\end{gathered}
$$

Dependent variable $=$ Financial leverage risk $($ FLR $)$.

$\boldsymbol{\beta}_{\boldsymbol{0}}=$ denotes a constant of the regression equation.

$\boldsymbol{\beta}_{\boldsymbol{1}}=\mathbf{L Q}$ denotes regression coefficient of liquidity.

$\boldsymbol{\beta}_{2}=$ PRO denotes a control variable, regression coefficient of profitability. 
$\boldsymbol{\beta}_{3}=$ IND denotes a control variable, regression coefficient of type of industry. Industry dummies representing industry $\mathrm{j}$ where $\mathrm{j}=1,2,3, \ldots, 16$.

It $=$ Firm $\mathrm{i}$ in period $\mathrm{t}$.

$\mathbf{T}_{\mathbf{i}}=$ Year fixed effect.

$\varepsilon=$ Standard error term.

Second, the following regression model is used to test the impact of financial leverage risk and liquidity position on earnings per share (using profitability, and company industry type as a control variables).

The function of earnings per share ratio can be rearranged as follows: EPS $=f\left(F_{L R}, L_{i t}, P_{\text {it }}, I_{\text {ind }}, T_{i}\right)$ Where:

$$
\mathrm{EPS}_{\mathrm{it}}=\beta_{0}+\beta_{1} \mathrm{FLR}_{\mathrm{it}}+\beta_{2} \mathrm{LQ}_{\mathrm{it}}+\beta_{3} \mathrm{PRO}_{\mathrm{it}}+\beta_{4} \mathrm{IND}_{\mathrm{it}}+\mathrm{T}_{\mathrm{i}}+\varepsilon \mathrm{i}_{\mathrm{t}}
$$

Dependent variable $=$ Earnings per share $($ EPS $)$, It measures the return that ordinary shareholders earn from their investment in the firm.

$\boldsymbol{\beta}_{0}=$ denotes a constant of the regression equation.

$\boldsymbol{\beta}_{\boldsymbol{1}}=$ FLR denotes regression coefficient of financial leverage risk, which is the portion of debt used by the company in its capital structure.

$\boldsymbol{\beta}_{2}=\mathbf{L Q}$ denotes regression coefficient of liquidity, which is the extent to which a company has cash to meet short term obligation or assets that can be converted into cash easily.

$\boldsymbol{\beta}_{3}=$ PRO denotes a control variable, regression coefficient of profitability.

$\boldsymbol{B}_{4}=$ IND denotes a control variable, regression coefficient of type of industry. Industry dummies representing industry $\mathrm{j}$ where $\mathrm{j}=1,2,3, \ldots, 16$.

It $=$ Firm $\mathrm{i}$ in period $\mathrm{t}$.

$\mathbf{T}_{\mathbf{i}}=$ Year fixed effect.

$\varepsilon=$ Standard error term.

Third, the following regression model is used to test the impact of financial leverage risk and liquidity position on dividends yield (using profitability, and company industry type as a control variables).

The function of dividends yield ratio can be rearranged as follows:

$$
D Y=f\left(F^{\prime} R_{i t}, L_{i t}, P R O_{i t}, I N D_{i t}, T_{i}\right)
$$

Where:

$$
D Y_{i t}=\beta_{0}+\beta_{1} F_{L} R_{i t}+\beta_{2} L Q_{i t}+\beta_{3} P_{R O} O_{i t}+\beta_{4} I N D_{i t}+T_{i}+\varepsilon i_{t}
$$

Dependent variable $=$ Dividends yield $($ DY $)$.

$\boldsymbol{\beta}_{0}=$ denotes a constant of the regression equation. 
$\boldsymbol{\beta}_{\boldsymbol{1}}=\mathbf{F L R}$ denotes regression coefficient of financial leverage risk.

$\boldsymbol{\beta}_{2}=\mathbf{L Q}$ denotes regression coefficient of liquidity.

$\boldsymbol{\beta}_{3}=$ PRO denotes a control variable, regression coefficient of profitability.

$\boldsymbol{B}_{4}=$ IND denotes a control variable, regression coefficient of type of industry. Industry dummies representing industry $\mathrm{j}$ where $\mathrm{j}=1,2,3, \ldots, 16$.

It $=$ Firm $\mathrm{i}$ in period $\mathrm{t}$.

$\mathbf{T}_{\mathbf{i}}=$ Year fixed effect.

$\varepsilon=$ Standard error term.

\subsection{Earnings per Share}

The firm profitability and stock market performance is indicated by its earnings per share, which is the portion of companies profit allocated to each outstanding share of common stock. EPS after tax is being taken because dividend is paid from net earning after interest, taxes and after depreciation. EPS is calculated by dividing calculated net earnings by number of common share outstanding. Investors are much attracted to a company that shows positive signs that it has potentials of earnings both in the short and the long-term. Logically, this attraction could lead increase demand of its equity shares and consequently, the market share prices appreciated (Oliver and Ugah, 2015).

\subsection{Dividend Yield}

Dividend yield shows how much dividends a company pays out each year from its earnings instead of reinvestment relative to its share price. It represents the return on investment for a stock. Dividend yield indicates how much cash flows the company is getting for each shilling in an equity position (Margaret et al., 2015). Rapidly growing companies usually tends to have low dividend yield ratios, whereas, more mature companies tends to have higher one.

Dividend yield ratio is calculated by adding all cash dividends paid to common stockholders during the year and dividing them by the average market price of the stock (the stock price is at the end of financial year, when all the dividend announcements have been made).

Investors who demand a minimum cash flow stream from their investment portfolio can secure this cash flow by investing in shares they pay relatively stable high dividend yields. But at the same time, high dividends 
payments often come at the cost of firm potential growth as paying cash dividends to shareholders means not reinvesting it in an effort to make future capital gains. Therefore, while paying dividends to stock holders are attractive to investors, but it may be costly to them as, shareholders can earn high returns if the value of their stock increases while they hold it.

\subsection{Financial Leverage}

Firms combine both debt and equity in its financing. Financial leverage, gearing, or trading on equity is the use of the fixed -cost sources of funds in the capital structure, such as debt and preferred stock. Debt is more risky as it at the maturity must be returned back, thus management that utilizes less debt in the company capital structure tends to pay higher dividends and vise versa. This is because of companies with high financial leverage need to protect their creditors by making cash available for paying them and ensuring long-run solvency (Saghir and Hasan, 2015).

Nor Liyana et al., (2014) noted that greater investment risk is reflected by the higher leverage, as for companies asymmetric information caused external financing to be too costly; therefore companies prefer to use of internal financing more than external one. Only in case of when internal fund is not available, companies turn to external funding

The optimal capital structure also depend on tax policy, bankruptcy costs and on overall corporate risk as high corporate rates is in the favor of issuing debt, high personal tax rates is in the favor of issuing equity.

Companies that select to use high level debt for financing should have a tax shield advantage, but on the other hand, this high leverage is a financial risk signal and will put the management in a position to prioritize between paying dividend and liabilities.

Generally, companies that are aggressive in financing its expansion and growth with high debt over equity financing will encounter high financial risk. This will cause both volatile earnings due to the high interest expenses and volatile cash flow because at the debt maturity the principal amount must be paid payments. In case of the use of high debt in financing business operations, the business could potentially generate more EPS than it would have without this external financing. If the company increase its earnings over the amount it paid as an interest on debt, this will be a benefit for current shareholders as more earnings are being spread among the same number of shares, but on the other worse side, the stated interest on 
borrowed fund and the need to repay the principal can outweigh this benefit. Consequently, companies using high leverage paying fewer dividends to reserve their cash flow to maintain it in order to mitigate financial risks. Thus, this will decrease dividend payout, this support the free cash flow hypothesis which assumes that managers' use cash first to repay debt instead of paying dividend (Jensen, 1986).

In addition, it is thought that business with high debt/equity ratio may make future financing difficult and tend to have little new-financing capacity, because of the bankruptcy threat and the attendant fixed costs.

\subsection{Liquidity}

Liquidity reflects a company's financial health and it affects the investor's attractiveness towards a stock as they usually expect and require higher returns on assets which are sensitive to liquidity.

Liquidity and dividend policy are much linked since the companies that pay out dividends must consider the firm liquidity position. Distribution of cash dividends depends on both the free cash flow and profitability, as the former is the amount of cash flow from operating activities that remains after payment for capital expenditures (Margaret et al., 2015), thus, the greater the liquidity, the better the ability of the firm to pay dividend.

The signaling theory indicates that companies with higher cash availability are more able to pay higher dividends than those with less sufficient cash flow. Some companies are still willing in spite of their high leverage levels to increase debt to pay dividends from it, in order to send a strong positive signal to current owners or potential investors to maintain access to capital and enhance its reputation (Myers and Frank, 2004).

According to the agency theory, in order to diminish the agency conflict between their shareholders and managers, companies with high cash flows pays higher dividends. Otherwise, managers will work for their own personal goals to maximize their personal wealth instead of maximizing the shareholders wealth.

Dividend payout usually involve cash outflow as most of companies do not wish to distribute stock dividends or pay dividend in any another form.

It must note that, a company may have adequate earnings and good profits to declare dividends but it may have insufficient cash and liquidity problem to payout dividends. 
Cash dividend may be difficult due to lack of insufficient cash position which is a vital consideration in dividends payout. If case the company has liquidity problem, its management will continuously need funds for financing growing fixed assets and working capital and it will not be able to declare cash dividends and sacrifice to issuing stock dividends (Margaret et al., 2015).

Current ratios are used as indexes of a company's financial health. Liquidity problem is indicted by the current ratios low values (less than one) that reflect that a company may have operating and solvency difficulty in meeting its current obligations when comes due. On the other side, businesses can operate with a low current ratio if it has good prospects on the long-term, it may have no problem in borrowing against those future prospects to pay current obligations.

Balanced current ratio is useful for a business, as a very high liquidity is also problematic and it might indicate that the company management is a lot of unused cash resources that have to put it to work.

In financial markets, it is believable that the more liquid a stock is preferable and indeed investors have dividend preference based on the liquidity of the stock. Stocks that pay more dividends to satisfy investor's demands for liquidity are very important for them.

\subsection{Profitability}

Profitability ratio is one of this research control variables and it is the efficiency of a company in generating profit. For long ago, profitability has been considered as the most essential determinants of a company's ability to pay dividends (Ayman, 2015). Higher dividend payout ratio is linked with the ability of the company to generate stable and adequate profits and cash flow.

According to the signaling theory of dividend policy, profitable companies are paying higher dividends amounts as a signal about their good financial performance.

Corporation's profitability, in this research, is measured as return on equity or net income divided by total equity. ROE indicates how much profit the company generates with the equity shareholders have invested and it is used to evaluate the company-wide overall performance and also to evaluate individual investments that require investor financing (Culp, 2006). 


\subsection{Industry Type}

Industry type is one of this research control variables. Dividend policy decisions are affected by the differences between industries. According to Anil and Kapoor (2008), firms that are in a service industry are labor intensive, while, in manufacturing industry, large capital assets are required for their operations. Since the funds required for manpower recruitment and retention are relatively less than the funds needed for investment in capital assets, it is claimed that service firms have high liquidity than manufacturing ones. Consequently, high liquid firms can easily pay high dividends and vise versa for less liquid firms.

\section{Statistical Results Analysis}

The data for this research is gathered from the annual financial statements of the 114 companies from 16 industries. The collected data are for non financial companies listed at Egyptian Stock Exchange from the period 2014 - 2019.

\subsection{Descriptive Statistics Analysis}

The descriptive statistics (mean, median, standard deviation, minimum and maximum) of all research variables used includes the information of earnings per share, dividend yield, leverage; liquidity and profitability of all the 114 company from the 16 industry for the period of 2014 to 2019 are presented on table (2). The normality test was done and the data are determined to normally distribute.

Table (2): Descriptive Statistics of dependent and independent variables

\begin{tabular}{lccccc}
\cline { 2 - 6 } & EPS & DY & Leverage & Liquidity & Profitability \\
\hline N Valid & 567 & 567 & 567 & 567 & 567 \\
Mean & 1.929 & 4.831 & 20.122 & 2.361 & 11.884 \\
Median & 0.520 & 3.780 & 6.630 & 1.470 & 10.980 \\
Std. & 3.253 & 4.929 & 25.941 & 3.362 & 15.246 \\
Deviation & & & & & -52.16 \\
Minimum & 0.00 & 0.00 & 0.00 & 0.00 & 78.80 \\
Maximum & 17.73 & 20.59 & 99.60 & 35.34 & \\
\hline
\end{tabular}




\subsection{Correlation Matrix Analysis}

Correlation analysis is employed to test the multicollinearity among the dependent, independent and control variables used in the research. Table (3) shows that all independent variables are not correlated with each other as all the VIF values are much less than 5.

\begin{tabular}{ccc}
\multicolumn{3}{c}{ Table (3): Multicollinearity } \\
\hline Variable & VIF & 1/VIF \\
\hline Leverage & 1.04 & 0.959 \\
Liquidity & 1.03 & 0.973 \\
Profitability & 1.02 & 0.984 \\
\hline Mean VIF & 1.03 & \\
\hline
\end{tabular}

Pearson correlation is used to measure the strength of the linear relationship between the independent variables and the dependent one. Table (4) shows the correlation coefficients between the variables included in three regression models.

Correlation coefficients indicates a strong statistically significant negative relationship (-.161) between financial leverage and liquidity position at 0.01 significance level $(\mathrm{P}>0.05)$. Accordingly, the first hypothesis is accepted.

Earnings per share have reported a strong statistically significant positive relationship with the dividend yield (.424) and profitability (.434) $(\mathrm{P}<$ $0.05)$. Earnings per share are found to have strong statistically significant negative relationship with financial leverage (-.191) and an insignificant negative relationship with liquidity level (-.015) at 0.05 significance level $(\mathrm{P}>0.05)$.

Accordingly, the second hypothesis is accepted, while the third hypothesis is rejected.

Dividend yield ratio has reported a strong statistically significant positive relationship with the earnings per share (.424) and profitability (.347) $(\mathrm{P}<$ 0.05). An insignificant negative relationship between dividend yield ratio and liquidity level $(-.061)$ is found at 0.05 significance level $(P>0.05)$. Dividend yield ratio has reported a strong statistically significant negative relation with leverage (-.203) $(\mathrm{P}<0.05)$. Accordingly, the fourth hypothesis is accepted, while the fifth hypothesis is rejected.

The results is consistent with the logic that the financial risk is associated with the firm ability to meet its debt obligations along with its fix charges, 
thus financial leverage affects negatively and significantly the firm earnings per share and its ability to generate stable income for common stockholders in terms of dividends distributed.

Also, the results match with the fact that investors highly concentrate on dividend yield. Common shareholders demand more dividends distribution and on the other side, the firm needs more money to meet the fixed interest obligations to creditors, this high weighted average cost of capital will affect negatively the firm's liquidity position and growth retarded.

Table (4): Correlation Matrix Analysis

\begin{tabular}{|c|c|c|c|c|c|c|}
\hline & & EPS & DY & Leverage & Liquidity & Profitability \\
\hline EPS & $\begin{array}{l}\text { Pearson } \\
\text { Correlation } \\
\text { Sig. (2-tailed) } \\
\text { N }\end{array}$ & $\begin{array}{r}1 \\
567 \\
\end{array}$ & $\begin{array}{l}.424^{* *} \\
.000 \\
567\end{array}$ & $\begin{array}{c}-.191^{* * *} \\
.000 \\
567 \\
\end{array}$ & $\begin{array}{l}-.015 \\
.730 \\
567\end{array}$ & $\begin{array}{c}.434^{* *} \\
.000 \\
567\end{array}$ \\
\hline DY & $\begin{array}{l}\text { Pearson } \\
\text { Correlation } \\
\text { Sig. (2-tailed) } \\
\text { N }\end{array}$ & $\begin{array}{l}.424^{* *} \\
.000 \\
567\end{array}$ & 567 & $\begin{array}{c}-.203^{* *} \\
.000 \\
567\end{array}$ & $\begin{array}{c}-.061 \\
.144 \\
567\end{array}$ & $\begin{array}{c}.347^{* *} \\
.000 \\
567\end{array}$ \\
\hline Leverage & $\begin{array}{l}\text { Pearson } \\
\text { Correlation } \\
\text { Sig. (2-tailed) } \\
\text { N }\end{array}$ & $\begin{array}{c}- \\
.191^{* *} \\
.000 \\
567\end{array}$ & $\begin{array}{c}-.203^{* *} \\
.000 \\
567\end{array}$ & 567 & $\begin{array}{c}-.161^{* *} \\
.000 \\
567 \\
\end{array}$ & $\begin{array}{c}-.122^{* * *} \\
.004 \\
567 \\
\end{array}$ \\
\hline Liquidity & $\begin{array}{l}\text { Pearson } \\
\text { Correlation } \\
\text { Sig. (2-tailed) } \\
\text { N }\end{array}$ & $\begin{array}{l}-.015 \\
.730 \\
567\end{array}$ & $\begin{array}{l}-.061 \\
.144 \\
567\end{array}$ & $\begin{array}{c}-.161^{* *} \\
.000 \\
567\end{array}$ & 567 & $\begin{array}{l}-.003 \\
.941 \\
567\end{array}$ \\
\hline Profitability & $\begin{array}{l}\text { Pearson } \\
\text { Correlation } \\
\text { Sig. (2-tailed) } \\
\text { N }\end{array}$ & $\begin{array}{l}.434^{* *} \\
.000 \\
567\end{array}$ & $\begin{array}{l}.347^{* *} \\
.000 \\
567\end{array}$ & $\begin{array}{c}-.122^{* *} \\
.004 \\
567\end{array}$ & $\begin{array}{l}-.003 \\
.941 \\
567\end{array}$ & 567 \\
\hline
\end{tabular}

** Pearson correlation is significant at the 0.01 level (2-tailed).

\subsection{OLS Pooled Cross-Sectional Regression Analysis}

Cross-sectional data refers to data collected by observing and comparing the differences between many variables without regard to differences in time. Regression analysis is used to predict the value of one variable on the basis of other variables. This research has analyzed the impact of financial leverage, liquidity and firm financial performance on earnings per share and dividend yield. 
The correlation coefficients between the independent variables are presented in table (5); it shows the strength and the direction of the relationship between any pair of independent variables using OLS pooled cross-sectional time-series regressions with robust standard errors clustered at the firm level.

In support of hypothesis 2, the statistical results show a strong significant relationship between financial leverage risk and profitability and earnings per share in regression model 2 (t-stat. $=-4.16$ and 7.59 respectively), is statistically significant at $95 \%$ confidence level $(\mathrm{P}<0.05)$.

The liquidity has negative relationship with the company earnings per share in regression model 2 ( $\mathrm{t}$-stat. $=-3.16$ ), is statistically insignificant at 95\% confidence level $(\mathrm{P}<0.05)$ and these results cause hypothesis 3 to be rejected.

In support of hypothesis 4, the statistical results show a significant relationship between financial leverage risk and profitability and dividend yield in regression model 3 (t-stat. $=-5.64$ and 6.07 respectively), is statistically significant at $95 \%$ confidence level $(\mathrm{P}<0.05)$.

The liquidity has negative relationship with the company dividend yield and dividend patterns in regression model 3 (t-stat. $=-5.17)$, is statistically insignificant at $95 \%$ confidence level $(\mathrm{P}<0.05)$ and these results cause hypothesis 5 to be rejected.

The financial leverage has a negative impact on dividend policy; as companies with high financial leverage are tend to pay low dividends. Expectedly, the results show significant relationship between financial leverage and dividend yield. In the Egyptian stock exchange market the financial leverage is affecting the dividend policy, which indicates that the debt amount in the capital structure is affecting greatly the profit distribution among the shareholders of the company.

The higher the leverage degree, the lower the dividends pay out. This means that in order to attract external debt, then the firm need to lower its dividend payout. Also, company need to put necessary measures to avoid cases of liquidation.

As per the results reported in table (5), support the fact that a company's liquidity is the ability to sell its assets in the market without incurring potential losses since its price can be determined with certainty. If the company posses a weak liquidity position, a threat to solvency and inability to meet its obligations. 
According to the first regression model, only $14.62 \%$ of the firm's liquidity during the course of this research can be explained by the independent variable of financial leverage.

As per the results reported in table (6), earnings per share ratio as the dependent variable of hypotheses 2 and 3 has a positive relationship with the return on equity ratio which represent the profitability of the company and is statistically significant at $95 \%$ confidence level $(\mathrm{P}<0.05)$. Earnings per share also show a negative relationship with the debt to equity ratio and current ratio which represent the leverage and liquidity of the company respectively and are statistically significant at $95 \%$ confidence level ( $\mathrm{P}<$ 0.05). Accordingly, the $\mathrm{H}_{2}$ is accepted, while $\mathrm{H}_{3}$ is rejected.

A positive coefficient sign with EPS and profitability has support the fact that when earnings of the company increases EPS and its value increases and also the dividends distributed to investors.

A company with higher leverage and in the same time has higher earnings can projected its future earnings with a greater accuracy. Thus, it can pay large proportion of its earnings as cash dividends with less financial leverage risk of not being able to pay its debt obligations when come due.

According to the second regression model, only $27.27 \%$ of the firm's earnings per share during the course of this research can be explained by the independent variables of financial leverage, liquidity and profitability. As per the results reported in table (7), dividend yield ratio as the dependent variable of hypotheses 4 and 5 has a positive relationship with the return on equity ratio which represent the profitability of the company and is statistically significant at $95 \%$ confidence level $(\mathrm{P}<0.05)$. Dividend yield ratio also shows a negative relationship with the debt to equity ratio and current ratio which represent the leverage and liquidity of the company respectively and is statistically significant at 95\% confidence level $(\mathrm{P}<$ $0.05)$. Accordingly, the $\mathrm{H}_{4}$ is accepted, while $\mathrm{H}_{5}$ is rejected.

According to the third regression model, $33.26 \%$ of the firm's dividend yield during the course of this research can be explained by the independent variables of financial leverage, liquidity and profitability.

Empirical results suggest that the higher (lower) the leverage, the lower (higher) the dividend.

Findings supports the claim that many companies take into account their creditors first then stockholders' expectations, i.e. pay first its obligations then distribute dividends to the stockholders, the management of the company should in case of having extra liquidity balance between paying 
dividend in order to be consistent with their stockholders expectations and at the same time implement its investment plans especially if it is a highly leveraged firms.

In answer to the main research questions, the statistical results shows that, financial leverage, and liquidity has an adversely effect on earnings per share and dividend yield, while profitability has a positive significant effect on them.

\section{- Hypothesis 1}

Table (5): Pooled Cross-Sectional Linear Regression Model

\begin{tabular}{|c|c|c|c|c|c|c|}
\hline Liquidity & Coefficient & $\begin{array}{c}\text { Robust } \\
\text { Std. Err. }\end{array}$ & $\mathbf{t}$ & $\mathbf{P}>|\mathbf{t}|$ & $\begin{array}{l}\text { [95\% conf } \\
\text { Interval] }\end{array}$ & \\
\hline Leverage & -.023 & .006 & -3.65 & 0.000 & -.035 & -.010 \\
\hline Resources & -.493 & .445 & -1.11 & 0.269 & -1.368 & .381 \\
\hline Chemicals & 3.40 & 1.337 & 2.54 & 0.011 & .773 & 6.022 \\
\hline Construction & 0.098 & .433 & 0.23 & 0.821 & -.753 & .949 \\
\hline Financial & -.973 & .458 & -2.12 & 0.034 & -1.873 & -.072 \\
\hline Services & 0.044 & .581 & 0.08 & 0.939 & -1.097 & 1.187 \\
\hline Food Beverages & .494 & .464 & 1.06 & 0.288 & -.418 & 1.407 \\
\hline Healthcare & 1.033 & .483 & 2.13 & 0.033 & .082 & 1.983 \\
\hline Industrials & 2.352 & .519 & 4.53 & 0.000 & 1.332 & 3.371 \\
\hline Oil Gas & 0.063 & .502 & 0.13 & 0.900 & -.923 & 1.049 \\
\hline Personal & -.103 & .438 & -0.24 & 0.813 & -.965 & .757 \\
\hline Household & 1.061 & .586 & 1.81 & 0.071 & -.090 & 2.212 \\
\hline Real Estate & -.893 & .411 & -2.17 & 0.030 & -1.70 & -.085 \\
\hline Retail & -1.078 & .553 & -1.95 & 0.052 & -2.166 & .009 \\
\hline Media & -.424 & .428 & -0.99 & 0.322 & -1.265 & .416 \\
\hline Technology & 2.855 & 1.234 & 2.31 & 0.021 & .430 & 5.280 \\
\hline Telecom & -.081 & .342 & -0.24 & 0.813 & -.754 & .592 \\
\hline Travel & -.077 & .308 & -0.25 & 0.802 & -.683 & .528 \\
\hline Y1 & .198 & .472 & 0.42 & 0.675 & -.729 & 1.126 \\
\hline Y2 & -.189 & .394 & -0.48 & 0.632 & -.963 & .585 \\
\hline Y3 & -.0056 & .420 & -0.01 & 0.989 & -.831 & .819 \\
\hline $\begin{array}{l}\text { Y4 } \\
\text { cons }\end{array}$ & 2.500 & .445 & 5.61 & 0.000 & 1.625 & 3.375 \\
\hline
\end{tabular}

Predictors: (constant), financial leverage

Dependent variable: liquidity

Number of obs $=567$

$F(21,545)=11.21$

Prob $>$ F $=0.000$

R-squared $=0.1462$

Root MSE $=3.166$ 
Table (6): Pooled Cross-Sectional Linear Regression Model Hypotheses 2 and 3

\begin{tabular}{|c|c|c|c|c|c|c|}
\hline $\begin{array}{l}\text { Earnings per } \\
\text { Share }\end{array}$ & Coefficient & $\begin{array}{l}\text { Robust } \\
\text { Std. Err. }\end{array}$ & $\mathbf{t}$ & $\mathbf{P}>\mid \mathbf{t}$ & $\begin{array}{l}{[95 \% \text { conf }} \\
\text { Interval] }\end{array}$ & \\
\hline Leverage & -.037 & .006 & -5.64 & 0.000 & -.050 & -.024 \\
\hline Liquidity & -.201 & .038 & -5.17 & 0.000 & -.277 & -.124 \\
\hline Profitability & .079 & .013 & 6.07 & 0.000 & .053 & .105 \\
\hline Resources & -2.510 & 1.644 & -1.53 & 0.127 & -5.741 & .719 \\
\hline Chemicals & .190 & .922 & 0.21 & 0.836 & -1.622 & 2.003 \\
\hline Construction & -.533 & .824 & -0.65 & 0.518 & -2.152 & 1.085 \\
\hline Financial & -3.024 & .939 & -3.22 & 0.001 & -4.870 & -1.179 \\
\hline Services & -.886 & .798 & -1.11 & 0.268 & -2.456 & .682 \\
\hline Food Beverages & -.988 & .921 & -1.07 & 0.284 & -2.797 & .821 \\
\hline Healthcare & -.459 & 1.332 & -0.35 & 0.730 & -3.077 & 2.157 \\
\hline Industrials & 3.860 & 1.599 & 2.41 & 0.016 & .718 & 7.003 \\
\hline Oil Gas & -1.152 & .916 & -1.26 & 0.209 & -2.952 & .647 \\
\hline Personal & -4.046 & .846 & -4.78 & 0.000 & -5.708 & -2.384 \\
\hline Household & 2.852 & 1.360 & 2.10 & 0.066 & .179 & 5.524 \\
\hline Real Estate & -4.566 & 1.464 & -3.12 & 0.002 & -7.443 & -1.689 \\
\hline Retail & 4.110 & 1.137 & 3.62 & 0.000 & 1.877 & 6.344 \\
\hline Media & -.922 & 2.169 & -0.43 & 0.671 & -5.183 & 3.339 \\
\hline Technology & -1.877 & 1.251 & -1.50 & 0.134 & -4.335 & .580 \\
\hline Telecom & -.006 & .6395 & -0.01 & 0.992 & -1.262 & 1.249 \\
\hline Travel & 1.038 & .667 & 1.56 & 0.120 & -.273 & 2.350 \\
\hline Y1 & -.069 & .632 & -0.11 & 0.913 & -1.3109 & 1.172 \\
\hline Y2 & -.654 & .606 & -1.08 & 0.281 & -1.846 & .537 \\
\hline Y3 & -.545 & .634 & -0.86 & 0.391 & -1.791 & .701 \\
\hline $\begin{array}{l}\text { Y4 } \\
\text { cons }\end{array}$ & 6.450 & .885 & 7.29 & 0.000 & 4.712 & 8.189 \\
\hline
\end{tabular}

Predictors: (constant), financial leverage, liquidity, profitability and industry type

Dependent variable: earnings per share

Number of obs $=567$

$F(23,543)=16.75$

Prob $>$ F $=0.000$

R-squared $=0.272$

Root MSE $=4.292$ 
Table (7): Pooled Cross-Sectional Linear Regression Model Hypotheses 4 and 5

\begin{tabular}{|c|c|c|c|c|c|c|}
\hline Dividend Yield & Coefficient & $\begin{array}{c}\text { Robust } \\
\text { Std. Err. }\end{array}$ & $\mathbf{t}$ & $\begin{array}{c}\mathbf{P} \\
>|\mathbf{t}|\end{array}$ & $\begin{array}{l}\text { [95\% conf } \\
\text { Interval] }\end{array}$ & \\
\hline Leverage & -.019 & .004 & -4.16 & 0.000 & -.028 & -.010 \\
\hline Liquidity & -.070 & .022 & -3.16 & 0.002 & -.113 & -.026 \\
\hline Profitability & .079 & .010 & 7.59 & 0.000 & .059 & .100 \\
\hline Resources & -4.769 & 1.991 & -2.39 & 0.017 & -8.682 & -.856 \\
\hline Chemicals & -3.932 & 2.087 & -1.88 & 0.060 & -8.033 & .167 \\
\hline Construction & -4.038 & 1.989 & -2.03 & 0.043 & -7.946 & -.131 \\
\hline Financial & -5.219 & 1.988 & -2.62 & 0.009 & -9.126 & -1.313 \\
\hline Services & -4.183 & 1.993 & -2.10 & 0.036 & -8.100 & -.267 \\
\hline Food Beverages & -3.105 & 2.018 & -1.54 & 0.124 & -7.070 & .859 \\
\hline Healthcare & -5.492 & 1.986 & -2.77 & 0.006 & -9.393 & -1.590 \\
\hline Industrials & .868 & 2.261 & 0.38 & 0.701 & -3.573 & 5.310 \\
\hline Oil Gas & -2.675 & 2.229 & -1.20 & 0.321 & -7.055 & 1.704 \\
\hline Personal & -5.570 & 1.995 & -2.79 & 0.005 & -9.491 & -1.649 \\
\hline Household & -5.968 & 1.991 & -3.00 & 0.003 & -9.880 & -2.057 \\
\hline Real Estate & -5.585 & 1.986 & -2.81 & 0.005 & -9.487 & -1.683 \\
\hline Retail & -4.727 & 1.976 & -2.39 & 0.017 & -8.609 & -.844 \\
\hline Media & -6.319 & 2.100 & -3.01 & 0.003 & -10.444 & -2.193 \\
\hline Technology & -3.996 & 2.016 & -1.98 & 0.048 & -7.958 & -.0343 \\
\hline Telecom & .601 & .426 & 1.41 & 0.159 & -.236 & 1.440 \\
\hline Travel & .108 & .3752 & 0.29 & 0.772 & -.628 & .845 \\
\hline Y1 & .051 & .380 & 0.13 & 0.893 & -.695 & .798 \\
\hline Y2 & .378 & .410 & 0.92 & 0.357 & -.428 & 1.185 \\
\hline Y3 & -.192 & .371 & -0.52 & 0.604 & -.922 & .536 \\
\hline $\begin{array}{l}\text { Y4 } \\
\text { cons }\end{array}$ & 5.712 & 1.985 & 2.88 & 0.004 & 1.812 & 9.613 \\
\hline
\end{tabular}

Predictors: (constant), financial leverage, liquidity, profitability and industry type Dependent variable: dividend yield

Number of obs. $=567$

$\mathrm{F}(23,543)=12.35$

Prob $>$ F $=0.000$

R-squared $=\mathbf{0 . 3 3 2}$

Root MSE $=2.713$

Figures $(2,3,4,5,6)$, compare between the different industries between years 2014-2019 in terms of the research variables, earnings per share, dividend yield, financial leverage, liquidity and profitability. Figure (2) shows that oil and gas then utilities companies have the highest EPS. Figure (3) shows that oil and gas, media, retail then technology companies 
have the highest DY. Figure (4) shows that household, retail, technology then travel and leisure companies have the highest financial leverage. Figure (5) shows that chemical, oil and gas then travel and leisure companies have the highest liquidity. Figure (6) shows that oil and gas then utilities companies have the highest profitability.

These results are consistent with the findings of regression model analysis. Figures (2 and 6) shows that the same industries (like oil and gas and utilities) that have the highest profitability levels also have the highest in EPS. Figures (3 and 4) shows that industries with high financial leverage have the lowest dividend yield like telecommunications and travel and leisure.

\section{Figure (2): Earnings per Share}

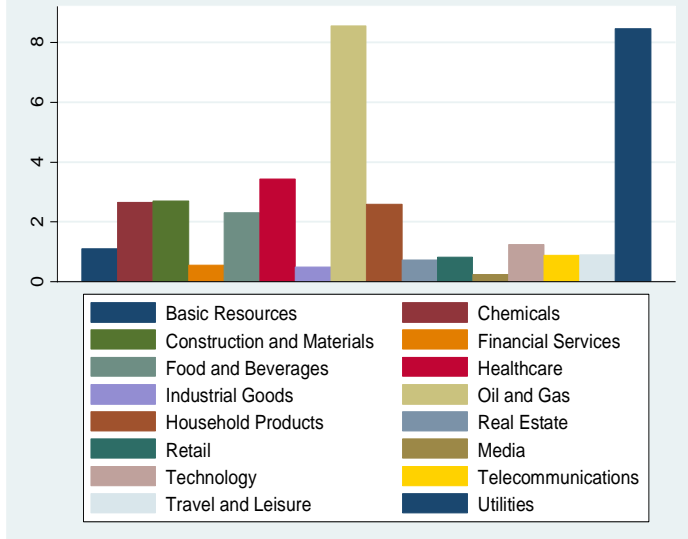

Figure (4): Financial Leverage

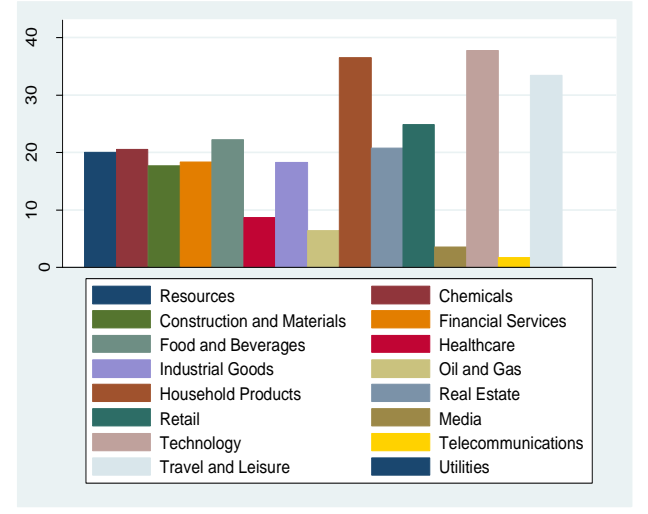

Figure (3): Dividend Yield

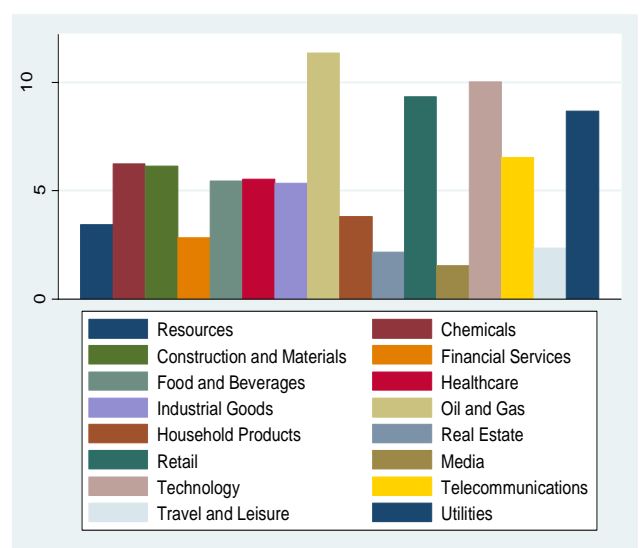

Figure (5): Liquidity

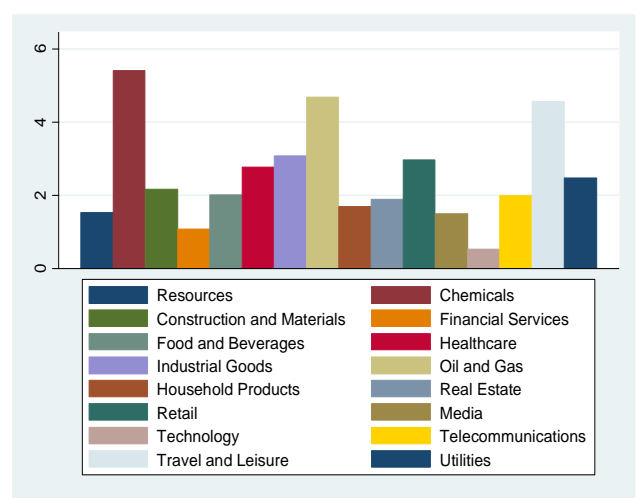


Figure (6): Profitability

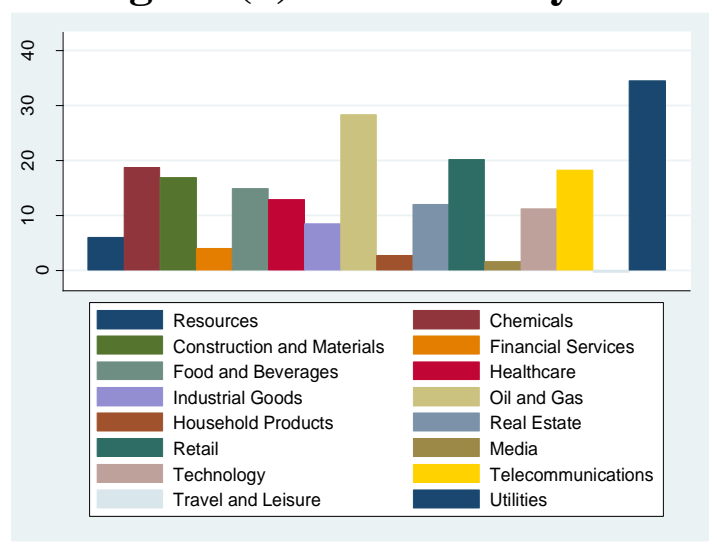

\section{Conclusion}

The purpose of this research is to test the impact of accounting disclosure of financial leverage and liquidity position on the earnings per share and dividend yield using a cross-sectional regression analysis based on data derived from the financial statements. A sample of 114 listed companies in Egyptian Stock Exchange is examined over the period from 2014 till 2019. The degree of financial leverage shows the level to which the company used external debt for financing its operations. The results revealed that there is a positive impact of profitability on both earnings per share and dividend yield. The results also revealed that all other independent variables (leverage and liquidity) had a negative association with both earnings per share and dividend yield. This research matches and harmonizes with other researches done in emerging economies and developing countries that portray a negative association between leverage and dividend policy, as companies needs to maintain adequate liquidity level to pay its debts. In addition it is appear that liquidity negatively impact profits, which portion of it will be distributed to investors.

Based on the regression results, liquidity has a negative relationship with leverage as the companies with higher leverage have less availability of cash to pay dividends to stockholder, while companies with low leverage have higher chances of pay dividends due to the avaliabity of cash. It showed that firms maintain high liquidity levels in order to settle debts as they came due. The findings also indicate that profitability has a major positive role in dividend yield, as companies which achieve high profit levels translated this to higher dividends paid out to investors. Profitability of a company is a main indicator of its capacity to distribute dividends. 
Company's ultimate goal is maximize the wealth of its shareholders and this can be achieved through the high earnings per share. Earnings per share are paid out of net income after tax therefore it is considered as an important factor that greatly affects dividend pay out. Significant positive relationship exists between earnings per share and the amount of dividend pay out. When the company reports high profit level, in turn the dividend yield will be higher.

Earnings per share had a significant effect on dividend yield; this means that if the share has a high return; the same will be translated to higher dividends.

Cash dividends are paid out of profits generated thus existence of positive correlation is expected. A higher profit rate is an important signal of higher dividend payout. Company's profitability has a great influence on the dividend pattern, as more profitable companies are willing to pay higher dividends and hence a positive significant relationship is found between company's profitability and its dividend pay out.

Also, company's leverage has a great negative influence on the company liquidity and the later in turn impact the decision to pay cash dividends. High-liquidity companies, i.e. companies with lower cash availability and near cash assets, pay lower dividends to shareholders than those with sufficient cash in hand available to pay as dividends.

Companies may maintain high liquidity level in order to pay financial obligations as they came due. High liquidity level strengthens company's ability to pay debts thus creditors' confidence is enhanced.

Generally, results from this research are much beneficial to investors as it can assist them in making the right decisions regarding their stock investment and determinants of dividend policy and pattern. The statistical results recommend that investors who expect high dividend pay out avoid investing in companies that have high financial leverage levels as these companies are less likely to pay dividends and are more likely to retain their available cash to settle their future debt obligations. 


\section{References}

1. Aasia Asif, Waqas Rasool and Yasir Kamal (2011). Impact of Financial Leverage on Dividend Policy: Empirical Evidence from Karachi Stock Exchange-Listed Companies. African Journal of Business Management, Vol. 5, No. 4, pp. 1312-1324.

2. Afza, T. and Mirza, H. (2010). Ownership Structure and Cash Flows as Determinants of Corporate Dividend Policy in Pakistan. International Business Research, Vol. 3, No. 3, pp. 210-221.

3. Anil K. and Kapoor, S. (2008). Determinants of Dividend Payout Ratios - A Study of Indian Information Technology Sector. International Research Journal of Finance and Economics, Vol. 15, pp.1-9.

4. Attiya YJ, Hafeez A. (2009). The Determinants of Dividend Policy in Pakistan. International Research Journal Finance and Economics, Vol. 25, pp.148-171.

5. Ayman I.F. Issa (2015). The Determinants of Dividend Policy: Evidence from Malaysian Firms. Research Journal of Financial and Accounting, Vol. 6, No. 18, pp. 205-230.

6. Banerjee, Gatchev, Spindt (2002). To Pay or Not To Pay? The Dividend Dilemma of the Liquid Firms. JEL Classification.

7. Ben-Zion, U. and Shalit, S. (1975). Size, Leverage, and Dividend Record as Determinants of Equity Risk. The Journal of Finance, Vol. 30, No. 4, pp. 1015-1026.

8. Culp, C. (2006). Structured Finance and Insurance. Hoboken, N.J.: Wiley.

9. Curran, W. S. (1987). Principle of Corporate Finance. Tokyo: Harcourt Brace Fovanovich.

10.Dalgaard, R. (2009). Liquidity and Stock Returns: Evidence from Denmark. Master's Thesis, Department of Economics, Copenhagen Business School.

11.Elangkumaran, P. and Nimalathasan, B. (2013). Leverage and its Impact on Earnings and Share Price: A Special Reference to Listed Companies of Colombo Stock Exchange (CSE) in Sri Lanka. International Journal of Technological Exploration and Learning, Vol. 2, No. 4, pp. 166-171.

12.Eljelly, A. M. A. (2004). Liquidity, Profitability Trade-off: An Empirical Investigation in an Emerging Market. International Journal of Commerce and Management, Vol. 14, pp. 46-51. 
13.Essa, M. S., et al., (2012). A Worthy Factors Affecting Dividends Policy Decisions, An Empirical Study on Industrial Corporations Listed in Amman Stock Exchange. Interdisciplinary Journal of Contemporary Research in Business, Vol. 4, No. 5, pp. 614-622.

14.Gill, A., Biger, N. and Tibrewala, R. (2010). Determinants of Dividend Payout Ratios: Evidence from United States. The Open Business Journal, Vol. 3, No. 8, pp. 8-14.

15. Gitman, L. J. and Zutter, C. J. Principles of Managerial Finance. $\left(13^{\text {th }}\right.$ Edition). Pearson.

16.Gugler, Klaus and Yurtoglu, Burcin (2003). Corporate Governance and Dividend Payout Policy in Germany. European Economic Review, Vol. 47, pp. 731-758.

17.Houmani, Mohammad Farahani, Ghara, Maryam Jhafari (2013). Impact of Financial Leverage on Dividend Policy at Tehran Stock Exchange: A Case Study in Food Industry. Journal of Natural and Social Sciences, Vol. 2, No. 3, pp. 2788-2801.

18.Jensen, G. R., Solberg, D. P. and Zorn, T. S. (1992). Simultaneous Determination of Insider Ownership, Debt, and Dividend Policies. The Journal of Financial and Quantitative Analysis, Vol. 27, No. 1, pp. 247-263.

19.Jensen, M. C. (1986). Agency Cost of Free Cash Flow, Corporate Finance and Takeovers. The American Economic Review, Vol. 76, No. 2, pp. 326-329.

20.Khan, N., Burton, B., and Power, D. (2011). Managerial Views about Dividend Policy in Pakistan. Managerial Finance, Vol. 37, No. 10, pp. 953-970.

21.Komrattanapanya, P. and Suntrauk, P. (2013). Factors Influencing Dividend Payout in Thailand: A Tobit Regression Analysis, International Journal of Accounting and Financial Reporting, Vol. 3, No. 2, pp. 255-268.

22.Kraus, A. and Litzenberger, R. H. (1973). A State Preference Model of Optimal Financial Leverage. Journal of Finance, Vol. 28, pp. 911922.

23.Kumar Jayesh (2003). Ownership Structure and Dividend Payout Policy in India. Journal of Emerging Market Finance, Vol. 5, No. 1, pp. 15-58. 
24.Lui, S. and $\mathrm{Hu}, \mathrm{Y}$. (2005). Empirical Analysis of Cash Dividend Payment in Chinese Listed Companies. Nature and Science, Vol. 3, No. 1, pp. 65-70.

25.Margaret Akinyi Olang, Grace Melissa Akenga, James Kamau Mwangi (2015). Effect of Liquidity on the Dividend Payout by Firms Listed at the Nairobi Securities Exchange, Kenya. Science Journal of Business and Management, Vol. 3, No. 5, pp. 196-208.

26. Mohamed et al., (2016). Empirical Analysis of Determinants of Dividend Payment: profitability and Liquidity. Online: http://www.wbiconpro.com/14\%5B1\%5D.Hui.pdf

27.Muhammad Usman Javed (2012). Impact of Financial Leverage on Dividend Policy: Case of Karachi Stock Exchange 30 Index. Journal of Contemporary Issues in Business Research, Vol. 1, No. 1, pp. 28-32.

28. Myers, M. and B. Frank. (2004). The Determinants of Corporate

Dividend Policy. Academy of Accounting and Financial Studies Journal, Vol. 8, No. 3, pp.17-28.

29. Narayana et al., (2014). Impact of Leverage, Capital Structure and

Dividend Policy Practices on Share holders Wealth in Larsen and Toubro Limited, India. International Journal of Advance Research in Computer Science and Management Studies, Vol. 2, No. 6, pp. 8-17.

30.Nor Liyana Mohd Anuar, et al. (2014). The Impact of Profitability, Liquidity, Leverage and Firm Size on Cash Dividend Payments for Public Listed Companies in Malaysia and Thailand. The Global Journal of Finance and Economics, Vol. 11, No. 2, pp.101-129.

31.Okpara, G. C., (2010). Diagnosis of the Determinants of Dividend Pay-Out Policy in Nigeria: Factor of Analytical Approach. American Journal of Scientific Research, Issue 8, pp. 57-67.

32. Oliver Ike Inyiama, Ugah Helen (2015). Interactions between Earnings and Dividend Payout Rate in the Oil and Gas Sector: Evidence from Nigeria (2004 - 2014). International Journal of Finance and Accounting, Vol. 4, No. 5, pp. 253-261.

33.Pandey I. M (2008). Financial Management. Vikas Publishing House PVT. Ltd.

34.Penman, S.H., S. A. Richardson and I. Tuna, (2007). The Book-toPrice Effect in Stock Returns: Accounting for Leverage. Journal of Accounting Research, Vol. 45, No. 2, pp. 427-467.

35. Perinpanathan Rajkumar (2014). Impact of Financial Leverage on Financial Performance: Special Reference to John Keells Holdings 
PLC in Sri Lanka. Scientific Research Journal (SCIRJ), Vol. II, No. II, pp. 15-20.

36.Rehman, S. S (2013). Relationship between Financial Leverage and Financial Performance: Empirical Evidence of Listed Sugar Companies of Pakistan. Global Journal of management and Business Research finance, Vol. 13, No. 8, pp. 33-40.

37.Ross, S.A., Westerfield, R. W. and Jaffe, J. (2011). Essential of Corporate Finance, Seventh Edition, McGraw-Hill, USA.

38.Saghir Ahmed and Hasan Murtaza (2015). Critical Analysis of the Factors Affecting the Dividend Payout: Evidence from Pakistan. International Journal of Economics, Finance and Management Sciences, Vol. 3, No. 3, pp. 204-212.

39. Thompson, R. (2000). Fundamentals of Corporate Finance. McGrawHill.

40.Twaijry, A. A. (2007). Dividend Policy and Payout Ratio: Evidence from the Kuala Lumpur Stock Exchange. The Journal of Risk Finance, Vol. 8, No. 4, pp. 349-363.

41.Waston D. and Head A. (2007). Corporate Finance; Principles \& Practice, $4^{\text {th }}$ Edition. 